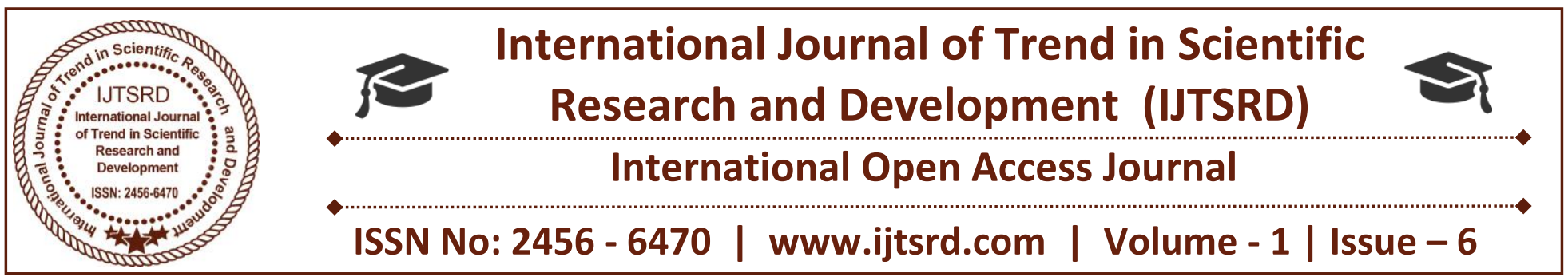

\title{
Evaluation of Feasibility of Interlinking of Rivers for Environmental Protection
}

\author{
Yogesh Renwal \\ Department of Civil Engineering, Maharishi Arvind \\ International Institute of Technology, Kota
}

\author{
Harish Uniyal \\ Department of Civil Engineering, Maharishi Arvind \\ International Institute of Technology, Kota
}

\section{ABSTRACT}

Interlinking of Rivers aims to link India's major river system by a network of reservoirs and canals so as to reduce persistent floods in some parts and water deficit in other parts of the country. The proposal is broadly categorized into three parts viz. the Northern Himalayan Rivers inter-link , the Southern Peninsular and an Intra-State Rivers linking components. The project is being studied by NWDA, under MWR. India receives about 4,000 through rainfall from June to mid- September. Moreover it is not uniform in space and time, results floods in one part and droughts in other. This geographical and time variance in availability of natural water versus the year round demand for irrigation, drinking and industrial water creates a demand-supply gap that has been worsening with rising population. The Proponents of the rivers inter-linking projects claim the answers to problem is to conserve the abundant monsoon water bounty, store it in reservoirs, and deliver this water through rivers inter-linking project

- to areas and over times when water becomes scarce. In addition the project also offer potential benefits to transport infrastructure through navigation, and fish farming. The National perspective plan envisions about 170 million acre feet of water for beneficial uses in India, enabling irrigation over an additional area of 35 million hectares, generation of 40,000 MW hydro power, flood control and other benefits. The cost of the project is invoices 6.5 lack crores as on 2003. Opponents are concerned about knowledge gap on environmental, ecological, social displacement impacts and unseen risks associated with tinkering with nature. Others are also concerned that some projects create international impact and the rights of nations such as Bangladesh and Nepal must be respected and negotiated.

Keywords: ILR- Interlinking of Rivers NWDANational Water Development Agency

\section{INTRODUCTION}

India plans to transfer water from the water surplus region of the north-east to the water scarce regions of western and southern India. It proposes 14 river links in the Himalayan, 14 in the Peninsular region and 37 intra-State river linking that will transfer water through a network of canals and reservoirs. Project cost estimated to Rs 5.6 lac crores as on 2002. The major benefits are additional irrigation to 34 million hectares of land, generation of $40,000 \mathrm{MW}$ of electricity, reduction of floods, and social upliftment. Many prominent experts and Social activists have criticized the project claiming that it will be not only a tinkering with nature but a financial, social and environmental disaster too.

\section{Background}

The idea of Inter-linking of Rivers in India not new it has a long history. It back since, 19th century to date by different workers with different Moto and concepts. However, the idea was revived in 1999 and proposal was modified to intra-basin development as opposed to previous inter-basin water transfer .By 2004, a different political alliance in power, and it resurrected its opposition to the project concept and 
plans .In February 2012, while disposing a PIL Supreme Court directed the Ministry of Water Resources to constitute an experts committee to pursue the matter with the governments as no party had pleaded against the implementation of Rivers Interlinking Project.

\section{The Need}

The nation has faced a number of cycles of drought and flood years, in major parts of west and south. This excess-scarcity regional disparity has created the need for water resources management. Rivers inter-linking is one proposal to address that need.

Drought, floods and shortage of drinking water: India receives about 4,000 km3 of rain annually. However, the precipitation pattern varies dramatically with space and time. Much of the precipitation (about $85 \%$ ), is received during summer months through monsoons in the Himalayan catchments of the Ganges-Brahmaputra-Meghna (GBM) basin. The north eastern region of the country receives heavy precipitation, in comparison with the north western, western and southern parts, but facing the problem of drinking water.

Population and food security: Population increase in India is the other driver of need for river inter-linking. The resulting demand for food must be satisfied with higher yields and better crop security, both of which require adequate irrigation of about 140 million hectares of land. Currently, just a fraction of that land is irrigated, and most irrigation relies on monsoon. Navigation: India needs infrastructure for logistics and movement of freight. Using connected rivers as navigation is a cleaner, low carbon footprint form of transport infrastructure, particularly for ores and food grains.

Current surface water reserves and declining ground water levels: currently India stores only 30 days of rainfall and it also relies excessively on groundwater, about. 15\% of India's food is being produced using rapidly depleting groundwater. India's ground water situation is already critical, and it needs sustainable development and management of surface water and groundwater usage.

\section{PLAN}

The National Perspective Plan starting comprised of:-

\section{Himalayan Link:}

The Himalayan Rivers' component envisages the construction of storages on the main Ganga, and the Brahmaputra as well in principal tributaries both in India and Nepal so as to conserve the monsoon flows and accrue benefits from, hydropower generation, irrigation and flood control. An interlinking canal system will be provided to transfer the surplus flows of the Kosi, Gandak and Ghagra to the west end of the Ganga and Yamuna to the Sutlej and Beas.

\section{Peninsular Link:}

The peninsular links includes. 14 river links which flow towards East and joining Bay of Bengal and 2 river links of rivers (river Narbada and Tapi) Which flow towards West and join Arabian Sea?

\section{Intra-states inter-linking of rivers:}

NDWA is entrusted to identify and complete the feasibility studies of intra-State projects that would inter-link rivers within that state. The various State Governments has submitted 37 numbers of proposals, while others not responded.

\section{CORE ISSUES}

\section{A. THE NATIONAL ISSUES}

\section{ECOLOGICAL AND ENVIRONMENTAL} ISSUES: Some activists and scholars have, questioned the merits of Indian rivers inter-link projects, which includes

$>$ Appropriate study of benefits and risks to environment and ecology has not been completed so far.

$>$ Knowledge gaps between the claimed benefits and potential threats from environment and ecological impact.

Whether the inter-linking project will deliver the benefits of flood control.

Uncertainty and unknowns about operations, how much water will be shifted and when, whether this may cause water logging, Stalinisation and the resulting desertification in the command areas of these projects. Whether there are other technologies to address the cycle of droughts and flood havocs, with fewer uncertainties about potential environmental and ecological impact. 


\section{DISPLACEMENT OF PEOPLE FISHERIES PROFESSION}

Water storage and distributed reservoirs are likely to displace people - a rehabilitation process that has attracted concern of sociologists and political groups

$>$ Further, the inter-link would create a path for aquatic ecosystems to migrate from one river to another, which in turn may affect the livelihoods of people who rely on fishery as their income.

$>$ Large dams, inter-basin transfers and water withdrawal from rivers is likely to have negative as well as positive impacts on freshwater aquatic ecosystem. As regards to the impact on fish and aquatic biodiversity, there could be positive as well as negative impacts.

\section{POVERTY AND POPULATION ISSUES}

India has a growing population, and large impoverished rural population that rely on monsoonirrigated agriculture. Weather uncertainties, raise concerns of social stability and impact of floods and droughts on rural poverty. This will increase demand for reliable sources of food and improved agriculture yields.

\section{FINANCIAL CHALLENGES}

Financing a project of this magnitude is going to be extremely challenging. Conservative estimates of the NWDA put the cost of the project at Rs 5, 60,000 crores as on year 2002. However, cost overruns on account of delays are quite expected. Even the minimum estimated equals $25 \%$ GDP, or two-and-ahalf times of our annual tax collection and double of our present foreign exchange reserves. Where is the investible capital of this magnitude available in the domestic market?

\section{OTHER ISSUES}

\section{Security:}

Security of network will be an enormous load on security forces of central and state governments. As canal can be easily breached by manual or natural activities.

\section{Technical Feasibility:}

The slope, altitude and other topographical aspects have to be considered. (e.g. for Ganga, Patna is divertible surplus but for raising water to Vindhyan chain i.e. 2860 ft. high enormous amount of power is required).

\section{POLITICAL VIEWS:}

The views of proponents and opponents of proposal changes with the Government in power in Centre. No definite conclusion can be drawn unless substantial technical and environmental supports.

\section{B. INTERNATIONAL ISSUES}

Inter-linking of rivers has a lack of an international legal framework India is proposing. In at least some inter-link projects, neighbouring countries such as Bangladesh and Nepal may be affected, and international concerns for the project must be negotiated.

\section{SHORT COMINGS AND DISCUSSION:}

1. The notion that there is huge surplus of water in river basins. This assumption is flawed. Most river basins today are overextended in usage, and in most regions tension is growing between old rural users of surface water and new industrial and urban users.

2. The notion that flood waters can be channelized is equally erroneous: The fact is when one river is in spate so is next river and transferring water would require huge storage facilities. Most river basins today are overextended in usage, and in most regions tension is growing between old rural users of surface water and new industrial and urban users.

3. A number of legal and constitutional experts have said, the Supreme Court has no mandate to ask the executive as to what projects it should take up. In that sense, this is an order that is entering the domain of the executive and hence is beyond the mandate of the judiciary.

4. As per Indian constitution, water is essentially a state subject that conflict with the nature's "Hydrological cycle" or water balance studies. No state is ready to give water to another state. States like Kerala, Andhra Pradesh, Assam and Sikkim have already opposed ILR plans. Orissa and Chhattisgarh have said there is no surplus in the Mahanadi basin, despite the fact the NWDA to do studies related to ILR. But none of the NWDA water balance studies involve such an exercise for a single basin or subbasin. In fact, the equation that flood means surplus and drought means deficit shows hydro-logical ignorance. There are states like Orissa, Bihar, Andhra Pradesh, Gujarat, Maharashtra and even Tamil Nadu that face drought or floods in different parts of the 
year. This is even true for Assam. It holds true for surplus basins like Ganga, Brahmaputra, Godavari and Mahanadi and so-called deficit basins like Betwa, Chambal, Krishna, Narmada, Tapi or Cauvery.

5. The notion that, by a diversion of mere 7 to $8 \%$ (4500 cusec water is to be lifted from a total flood flow of 60,000 cusecs.) of flood water can solve, or even mitigate floods is a mystery.

\section{Alternatives:}

Rain water harvesting: Wherever feasible, it increases groundwater recharge and can helps in preventing floods by reducing storm water runoff. The cost of such initiatives would be a fraction of the proposed river-interlinking plan and it would be easy to maintain and repair. The social cost of displacement would also not exist or be minimal. Most importantly, by making each village responsible for its own water security, this would encourage more responsible farming practices and would thus serve as a tool for social change, supporting poverty alleviation and providing communities' rights over resources.

\section{CONCLUSION}

India's ever increasing and widespread water crisis is the result of the culmination of myopic planning, muddled policies and misguided perceptions. With rapid development and urbanization, traditional systems of managing water resources were dismantled and thrown by the wayside. The total absence from the public domain of any technical and economic assessment report on this project surely creates a lack of comfort and confidence in the public mind on the wisdom behind such an investment decision. The citizens of India certainly expect the Government to be completely transparent and professional at all levels, before it gets a clearance for this mega project. On the supply side, reverse the ranking of big projects like river- interlinking project as primary and local water-harvesting and watershed-development programmes as secondary and supplementary; treat the latter as primary and the former as projects of last resort. 